\title{
原 著論文
}

マウスガードの咬合支持領域が咬みしめ時の下顎頭変位に与える影響 白野 美和 $^{\mathrm{a}}$ 永田 和裕 ${ }^{\mathrm{a}}$ 森田 修已 ${ }^{\mathrm{b}}$

\section{Influence of Occlusal Support of Mouthguard on Condylar Displacement during Clenching}

\author{
Miwa Shirono, DDS, $\mathrm{PhD}^{\mathrm{a}}$, Kazuhiro Nagata, DDS, $\mathrm{PhD}^{\mathrm{a}}$ and Osami Morita, DDS, $\mathrm{PhD}^{\mathrm{b}}$
}

\begin{abstract}
抄 録
目的：マウスガード ( 以下 $M G$ ) の装着が顎関節におよぼす影響については未だ不明な点が多い。そこで本 研究は，MGの咬合支持領域の違いが咬みしめ時の下䪽頭変位に及ぼす影響を明らかにする目的で，咬合 支持領域の異なる 3 種類の MG 装着時における最大咬みしめ ( 以下 MVC) 時の下顎頭変位を測定し検討 を行った。

方法：被験者は健常有歯顎者 10 名（平均年齢 27.1 歳）とした。咬合支持領域の異なる 3 種類の MG（前 歯から第二大臼歯まで全ての歯に咬合接触が存在する Type77, 第一大毛歯まで咬合接触が存在する Type66, 臼歯部のみに咬合接触が存在する Type47) を製作し, 咬頭嵌合位 (以下 ICP) と 3 種類の MG 装着時において，最大咬みしぬ（以下 MVC）時の下顎頭変位を超音波方式の下顎運動機能解析装置であ る Win Jaw システム ${ }^{\circledR}$ を用いて測定した。

結果: MVC 時の下顎頭変位量は ICP と比べ Type77，Type66 が上方への変位が有意に大きかった。また， ばらつきは前後方向において ICP に比べType66 のばらつきが有意に大きくなり, Type77に比べ Type66 と Type47 のばらつきが有意に大きくなった.

結論：前後の咬合支持を削除することにより，被験者によっては下顎頭位の前後的な安定性が減少するこ とが示唆された。

各咬合支持条件における下顎頭の変位量，変位方向は個人差が大きく，どのような咬合接触が適切である かについては明確な結論は得られなかった。
\end{abstract}

和文キーワード

マウスガード，顎関節，下顎頭変位，咬合支持領域，超音波方式下顎運動機能解析装置

\section{I . 緒 言}

上下顎の歯の強い咬みしめは，スポーツ活動や日常生 活において肉体的・精神的緊張時に無意識に発現するこ とが知られている ${ }^{1)}$.

スポーツ時の顎口腔領域の外傷予防にはマウスガー ド (以下 MG) の装着が有効であることが報告 ${ }^{2-4)}$ され ており，特にコンタクトスポーツにおいては不可欠なも
のとして普及しているが，ノンコンタクトスポーツにお いても過度な咬合力から歯, 歯周組織および顎関節を保 護する機能を有していることが報告されている ${ }^{5,6)}$ 。そ の一方で MGが装着されることにより咬合が挙上され ることや，弾性材料を使用することから咬みしめた際に さらに顎位が変化し，顎関節に何らかの影響を与える可 能性も考えられる。

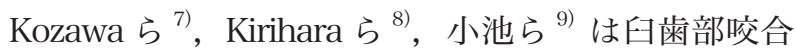
支持の喪失と咬みしめ時の下顎頭変位との関連性を検討

${ }^{\mathrm{a}}$ 日本歯科大学新潟病院総合診療科・あごの関節外来

b 日本歯科大学

a Comprehensive Dental Care Unit and TMD clinic, The Nippon Dental University Niigata Hospital

b The Nippon Dental University

受付 : 2008 年 11 月 5 日/受理 : 2009 年 5 月 21 日

Received on November 5, 2008/Accepted on May 21, 2009 
し，咬みしめ時の下顎頭変位量はオクルーザルスプリン トの咬合支持を後方から順次喪失させるのに伴い大きく なる傾向があったが，喪失範囲の拡大とともに被験者間 のばらつきが増大し, 変位しやすいグループと変位しに くいグループの二つに分かれることなどを明らかにして いる. しかし，この結果がそのまま MG 使用時に適合で きるかは不明であり， MG の咬合支持が咬みしめ時の下 顎頭変位に及ぼす影響は明らかではない.

このようなことから本研究は，MG の咬合支持領域の 違いが咬みしめ時の下顎頭変位に及ぼす影響を明らかに する目的で，咬合支持領域の異なる 3 種類の $\mathrm{MG}$ 装着時 における最大咬みしめ ( 以下 MVC) 時の下顎頭変位を超 音波方式による下顎運動機能解析装置を用いて測定した.

\section{II. 研究方法}

\section{1，被験者}

被験者は, 自覚的他覚的に顎口腔系に機能異常を認め ない健常有歯顎者 10 名 (男性 4 名, 女性 6 名, 平均年 齢 27.1 歳）とした。 なお，本研究は実験に先立って日 本歯科大学新潟生命歯学部倫理委員会の承認を得ると ともに（承認番号：院 117), 被験者に実験の内容を十 分に説明し，同意を得たうえで行った。

\section{2. $M G$ の製作}

各被験者の上下顎に対してアルジネート印象材 (Aroma Fine ${ }^{\circledR}$, GC) にて印象採得を行った後, 通法に 従って硬石膏（New Plastone ${ }^{\circledR}$, GC) にて作業模型を 製作，フェイスボウ（Hanau SM 顔弓 ${ }^{\circledR}$ ，Hanau）を用 いて半調節性咬合器 (Hanau H2-0 articulator $^{\circledR}$, Hanau）に装着した. $\mathrm{MG}$ の製作には厚さ $4 \mathrm{~mm} の$ EVA シート (BIOPRAST ${ }^{\circledR}$, SCHEU DENTAL) を使用し, 加圧成型器 (BIOSTAR ${ }^{\circledR}$, SCHEU DENTAL) にて加圧 成形し武田ら ${ }^{10)}$ の方法に準じて調製を行った。 MGの 咬合挙上量は下顎第一大臼歯近心煩側咬頭頂部で $2 \mathrm{~mm}$ とし, 咬合接触状態は咬合器上で下顎の各対合歯が最低 でも 1 カ所ずつ均等接触し, 対合歯の咬頭頂の圧痕が 0.5 $\mathrm{mm} \sim 1 \mathrm{~mm}$ 残るように調整した。咬合調整の際， 3 種類の MG の咬合接触領域における咬合接触を可及的 に一致させるよう，まず一つの $\mathrm{MG}$ を咬合器上で全歯 列が均等接触するように調整を行い, 口腔内においても 均等接触するよう, 口腔内に装着し調整を加え, この MG をもとに下顎模型の再装着を行い, 他の 2 つの MG の咬合調整を行った。

その後, 以下の咬合支持領域の異なる 3 種類の $\mathrm{MG}$ を製作した。

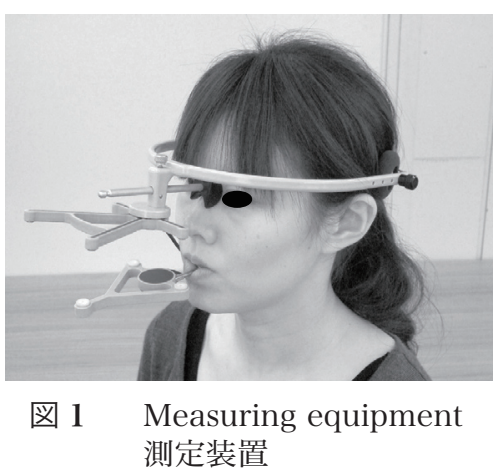

1）第二大臼歯までの全ての歯に咬合接触が存在する 状態 (以下 Type77).

2）第一大臼歯までの全ての歯に咬合接触が存在する 状態 (以下 Type66).

3）第一小臼歯から第二大臼歯までの臼歯部のみに咬 合接触が存在する状態 (以下 Type47).

Type66 においては，全歯列が均等接触するよう製作 した MG を後端が左右第一大臼歯遠心部となるようカッ トし，調整を行った。 Type 47 においては，全歯列が均 等接触するよう製作した $\mathrm{MG}$ の前歯部の咬合接触部を バーにて削除し, 口腔内に装着し最大咬みしめを行った 際に前歯が接触しないよう調整を行った。

以上の方法で製作した 3 種類の $M G$ を計測に使用した.

\section{MVC 時の下顎頭変位の測定}

1) 測定装置

下顎頭変位の測定には超音波方式による下顎運動機能 解析装置 (Win Jaw System ${ }^{\circledR}$, Zebris) を使用した (図 1). 本システムは本体 (CMS20JMA ベースユニット), フェ イスボウ, 発信機（トリプルマーカー），受信機（マイク ロフォン), 下㖽用クラッチ ( $\mathrm{T}$ 型アタッチメント), 下 顎頭点と眼窩下点を入力するポインターにより構成され ている.トリプルマーカーを下顎前歯部に固定したクラッ チに取り付け，マイクロフォンをフェイスボウで頭部に 固定し, 超音波波動をトリプルマーカーからマイクロフォ ンに送ることにより相対的位置関係を計算している，解析 には下顎頭位置解析ソフトウェア (EPA：Electronic position Analysis of the condyles) を使用し，解析デー夕を $0.001 \mathrm{~mm}$ 単位で ASCII ファイルに出力し, 処理を行った.

\section{2) 測定手順}

下顎用クラッチは下顎歯列唇側面に合わせて屈曲し, 即時重合レジン（プロビナイス ${ }^{\circledR}$ ，松風）にて前歯部か ら第一小臼歯遠心の唇側歯面に適合するよう調整した 後, シアノアクリレート系瞬間接着剤（デンタルシア） ン ${ }^{\circledR}$ ，高圧ガス工業社製）により歯面に固着した。この 
際にクラッチやその接合部は正常な咬合接触および $\mathrm{MG}$ 装着時の咬合接触を妨げないようにした。

測定基準平面は左右耳珠上縁と右側眼窩下点を結んだ フランクフルト平面とし，専用ポインターを使用して入 力を行った。 下顎頭の計測点は Win Jaw System ${ }^{\circledR}$ の推奨 する方法を使用した。すなわち耳珠上縁をポインターに て入力し，顆頭間軸上で両側の皮膚上のポイントを結ん だ距離の 68.4\%が両側の下顎頭中心を結んだ下顎頭間距 離となるというKorda $\beta ら^{11)}$ の研究における平均的下顎 頭点の算出方法に基づき内外側的な下顎頭中心点を決定 し，矢状面においては耳珠上縁から前方 $10.33 \mathrm{~mm}$ ，下 方 $3.60 \mathrm{~mm}$ となる点を算出し，下顎頭の代表点とした。 測定時の姿勢は上体を垂直にした座位で，約 $1 \mathrm{~m}$ 前方 の壁に自然頭位をとつた際に目とほぼ同じ高さになる よう視標を設置し，一定の頭位をとれるようにした。

測定は Type77, Type66, Type47 の各 MG 装着時と 咬頭嵌合位（以下 ICP）において，それぞれ軽く咬合し た状態と MVC 時について行った，各条件の測定順序は 被験者個々において無作為とし，測定誤差を減少させる ため，同一条件で 6 点計測を行うとともに，MVC 後の 疲労を考慮し MVC を行った後は次の測定までに 5 分間 の休㦝を設けた。

\section{4. 分析方法}

各条件において軽く咬合した時の下顎頭位と MVC 時 の下顎頭位の差を前後方向，上下方向，側方方向の各座 標について求め，MVCによる下顎頭の変位量とした。

ICP および MG 装着時の MVC による下顎頭変位量の 左右差について各咬合条件ごとに対応のある平均值の 差の検定を行った結果，全ての咬合条件において左右差 が認められなかったため，以下の分析においては右側の みを対象として分析を行った。

MVC による下顎頭変位量の咬合支持条件の違いよる 影響については Friedman 検定を行い，有意差の認めら れたものについては Bonferroni 検定を行った。また， 各咬合支持条件での下顎頭変位のばらつきの違いにつ いては F 検定（Bonferroni 補正）を行った。

\section{III. 結 果}

\section{ICP における MVC 時の下顎頭変位}

図 2 に ICP における MVC 時の下顎頭変位を示す。前 後方向の変位は前方 $0.33 \mathrm{~mm}$ から後方 $0.03 \mathrm{~mm}$ ，上下 方向では上方 $0.48 \mathrm{~mm}$ から下方 $0.16 \mathrm{~mm}$ ，側方方向で は外側 $0.15 \mathrm{~mm}$ から内側 $0.18 \mathrm{~mm}$ の範囲にあり，全 体では平均前方に $0.12 \pm 0.11 \mathrm{~mm}$ (平均土標準偏差 ; 以
下省略）,上方に $0.12 \pm 0.18 \mathrm{~mm}$, 外側に $0.01 \pm 0.08 \mathrm{~mm}$ の変位を示した。

\section{MG 装着時における MVC 時の下顎頭変位}

図 3, 図 4, 図 5 に Type77，Type66，Type47 装 着時における MVC 時の前後方向，上下方向ならびに側 方方向の下顎頭変位を示す．前後方向の変位は Type77 では前方 $0.28 \mathrm{~mm}$ から後方 $0.07 \mathrm{~mm}$ ，Type66 では前 方 $0.49 \mathrm{~mm}$ から後方 $0.52 \mathrm{~mm}$, Type47 では前方 0.44 $\mathrm{mm}$ から後方 $0.18 \mathrm{~mm}$ の範囲であった。上下方向の変 位は Type77では上方 $1.36 \mathrm{~mm}$ から上方 $0.13 \mathrm{~mm}$, Type66 では上方 $0.97 \mathrm{~mm}$ から下方 $0.09 \mathrm{~mm}$, Type47 では上方 $0.82 \mathrm{~mm}$ から下方 $0.06 \mathrm{~mm}$ の範囲であった。 側方方向の変位は Type77 では外側 $0.16 \mathrm{~mm}$ から内側 $0.07 \mathrm{~mm}$, Type66 では外側 $0.11 \mathrm{~mm}$ から内側 0.06 $\mathrm{mm}$, Type 47 では外側 $0.13 \mathrm{~mm}$ から内側 $0.07 \mathrm{~mm}$ の 範囲であった。

下顎頭の変位方向は被験者 A の Type66 装着時と Type47 装着時，被験者 B の Type66 装着時，被験者 $\mathrm{E}$ の Type77 装着時と Type66 装着時と Type47 装着時, 被験者 $\mathrm{G}$ の Type77 装着時と Type47 装着時，被験者 I の Type66 装着時においては下顎頭の後上方への変位が 認められ，被験者 Hの Type66 装着時と Type47 装着 時では前下方の変位が認められた。これ以外では下顎頭 は全て前上方へ変位した。

MG のタイプ別にみると Type66 では 4 関節が後方へ 変位し Type77, Type47 に比べて後方への変位が多く, 後方への変位量も Type77 で 0.06 mm, Type47 で最大 $0.17 \mathrm{~mm}$ に対し，Type66 では最大 $0.52 \mathrm{~mm}$ と比較的 大きな変位を示した。

図 6 に各咬合支持条件における MVC 時の下顎頭変位 量の平均值と標準偏差を示す。前後方向 (図 6-a)，側方 方向 (図 6-c) の変位量は各咬合支持条件の間に有意差 は認められなかった。上下方向の変位量については各咬 合支持条件の間に有意差が認められ $(p=0.043)$, Bonferroni の多重比較検定の結果, ICP と Type77, Type66 の間に有意差が認められ $(p=0.0074$, $p=0.0064)$, ICP と比べ Type77, Type66 は上方への 変位が有意に大きいことが認められた。

表 1 に各咬合支持条件間における MVC 時の下顎頭位 の F 検定結果について示す，MVC 時の下顎頭位のばら つきは，前後方向では ICP に比べ Type66 のばらつきが 有意に大きくなり，Type77 に比べ Type66 と Type47 のばらつきが有意に大きくなった。上下方向，側方方向 の下顎頭位のばらつきには有意差は認められなかった。 

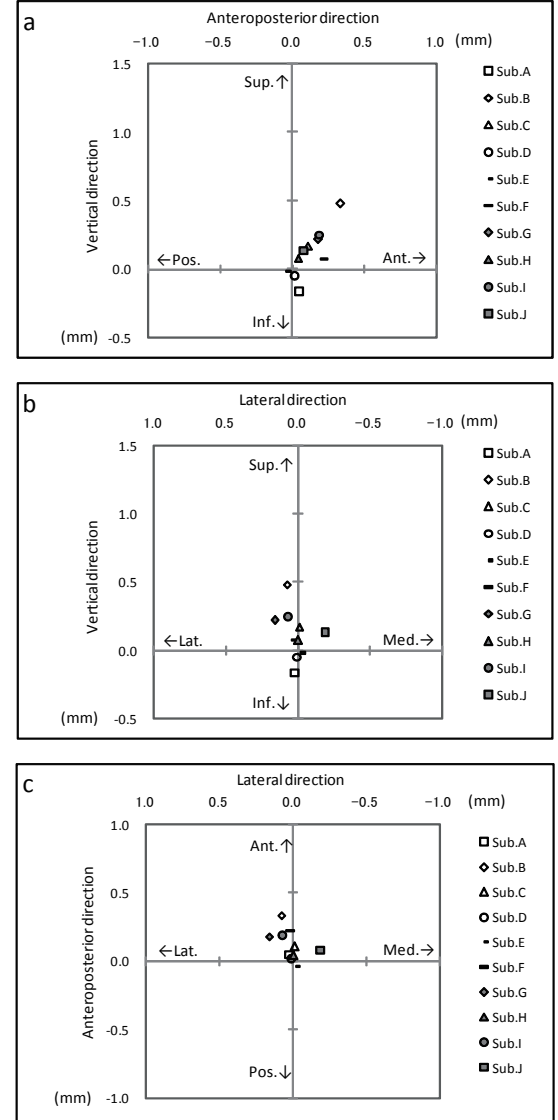

図 2 Displacement of condyle during MVC under ICP

a. Sagittal plane, b. Frontal plane, c. Horizontal plane

ICP における MVC 時の下顎頭変位

a. 矢状面, b. 前頭面, c. 水平面

\section{IV. 考 察}

$\mathrm{MG}$ 装着の目的は主に顎口腔領域における外傷の予防 であり，特にコンタクトスポーツでは使用が義務付けら れるべきである。しかしながら，MG 溦頁口腔系に与え る影響については未だ不明な点が多く残されている。実 際に MG 装着により顎関節の保護および顎の脱臼や骨 折を予防するという考えがある一方，MG はその弾性か ら下顎位を変化させることが確認され，顎関節に大きな 力が加わる可能性が指摘されており ${ }^{12)}$ ，使用において マイナスファクターも考元れることから，生理的作用 に関して十分な評価が必要であると考え，本研究では最 大咬みしめ時の下顎頭変位の定量的評価を行った。

\section{MG の交合支持領域について}

MG に与える咬合支持領域については統一した見解が
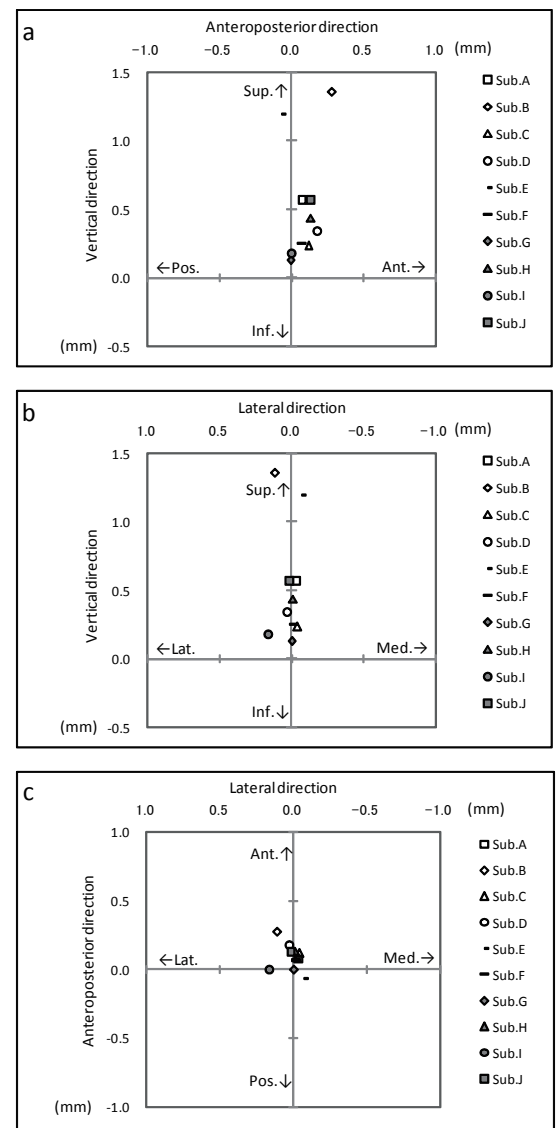

図 3 Displacement of condyle during MVC with Type77 MG

a. Sagittal plane, b. Frontal plane, c. Horizontal plane

Type77MG 装着時における MVC 時の下顎頭変位 a. 矢状面， b. 前頭面，c. 水平面

なく，競技の種類や術者の考えによって設定されている のが現状である。

一般的に $M G$ の後端は，第一大臼歯後緑，第二大臼 歯中央，第二大臼歯後縁などに設定され，この位置は装 着感や歯の萌出程度などによって決定される ${ }^{13,14)}$ 。ま た Yamanaka ら ${ }^{15)}$ は後端の位置を咬合力の分散という 観点から第二大臼歯後緑に設定すべきとしている.

前歯部の咬合接触については，臼歯部と同様に均等に 接触させるという方法 ${ }^{14)}$ もある一方，臼歯部と同様に 均等な咬合を与えるとクレンチング時に前歯部では天 然歯での咬合時よりも過㮃な力がかかるため，前歯部で はクレンチング時に軽く接触する程度にするか，もしく は接触をさせないという方法がある ${ }^{13)}$.

そこで本研究ではこれらの条件を考慮し，MGの咬合 支持を，1）第二大臼歯までの全ての歯に咬合接触が存 在する状態，2）後端を第一大臼歯までとし，第一大臼 

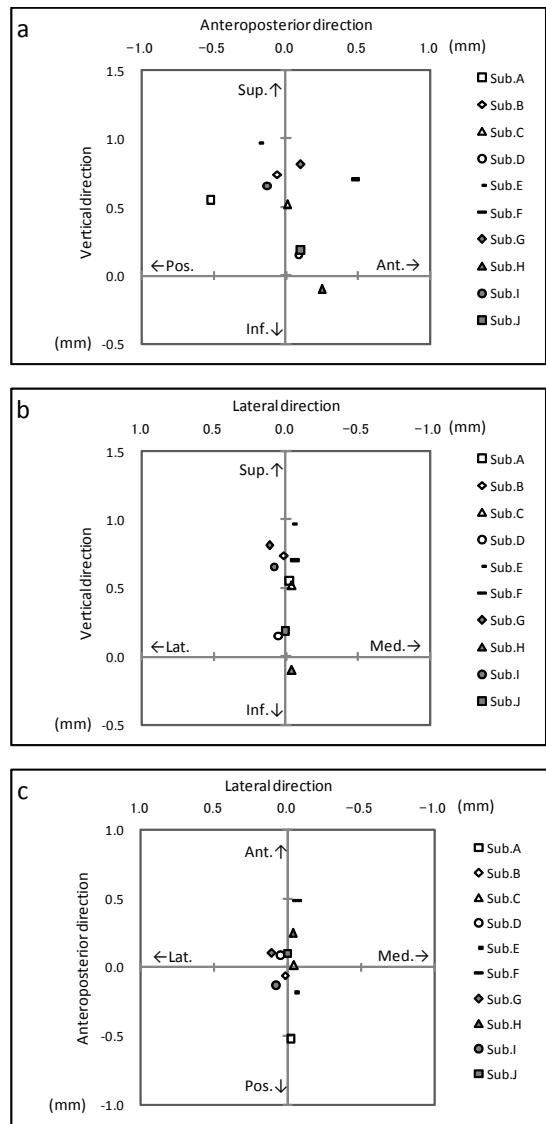

図 4 Displacement of condyle during MVC with Type66 MG

a. Sagittal plane, b. Frontal plane, c. Horizontal plane

Type66MG 装着時における MVC 時の下䫈頭変位 a. 矢状面, b. 前頭面, c. 水平面

歯までの全ての歯に咬合接触が存在する状態，3）前 歯部には咬合接触の存在がなく，第一小臼歯から第二大 臼歯までの臼歯部のみに咬合支持が存在する状態，の 3 条件とし, MVC 時の下顎頭変位について検討した。

\section{2. 下顎頭変位の測定方法について}

下顎頭の変位を測定する方法には，大別すると頭部や上 下顎歯列に顔弓などを装着しそれらの位置関係から測定す る方法 ${ }^{16,17)}$ と, X線写真から測定する方法 ${ }^{18,19)}$ とがある. 前者は下顎頭の変位を 3 次元的に捉えることができ，測定 精度が高く，測定点を明確にできるなどの利点がある。

本研究のように咬合力の負荷に伴う下顎頭変位を検 討する場合では，歯の変位や下顎骨の変形を考慮しなけ ればならないが，前者の方法では下顎を剛体と仮定して いるため, 誤差の生じる可能性が考えられる，後者の方 法はこの問題を回避することができるものの，被験者の
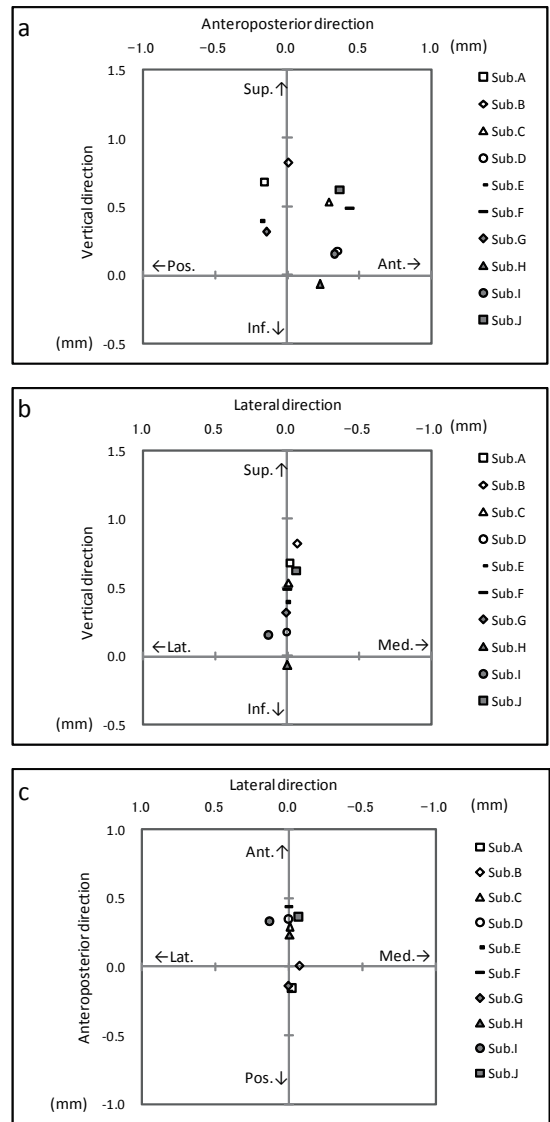

図 5 Displacement of condyle during MVC with Type 47 MG

a. Sagittal plane, b. Frontal plane, c. Horizontal plane

Type47MG 装着時における MVC 時の下顎頭変位 a. 矢状面， b. 前頭面，c. 水平面

被曝の問題，被写体フィルム間距離の誤差，再現性，鮮 鋭度の問題，撮影の角度により内外側への変位が上下方 向への変位のように撮影されるなどの問題点があり，そ れぞれに利点，欠点がある。今回のように，咬頭嵌合位 と 3 種類の MG 装着時の MVC による下顎頭の変位を 測定するにあたっては測定回数も多いため被曝量が多 くなることが懸念されること，また，MG という軟質の 材料を使用するため咬みしめた際の変位量が大きくな り, 前後方向だけでなく内外側にも大きく変位すること が予測されることから，本研究では前者の方法が適して いると判断した.

\section{3. 測定装置について}

本研究で使用した Win Jaw System ${ }^{\circledR}$ は被験者に装着 するセンサーが軽量で非接触式であることから，機能時 の下顗位を評価するのに適している。また，ソフトウェ 


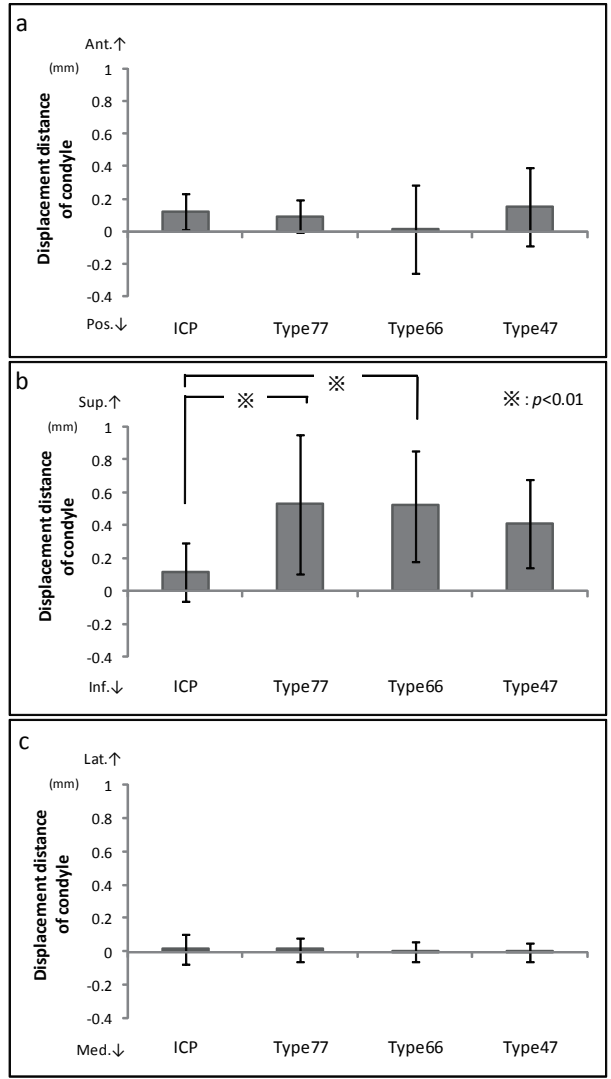

図 6 Displacement distance of condyle during MVC under each occlusal support conditions (mean value, standard deviation)

a. Anteroposterior direction, b. Vertical direction, c. Lateral direction

各咬合条件における MVC 時の下顎頭変位量（平 均值, 標準偏差)

a. 前後方向，b. 上下方向，c. 側方方向

アとしては顎関節位置評価（EPA）を備えており，下顎 頭の位置変化を連続的に記録できることなどの特徵を 有しており, 本研究の目的には適したものと考える.

著者ら ${ }^{20)}$ が行った装置の測定精度実験の結果では $\mathrm{EPA}$ の平均分解能は $51.9 \sim 53.9 \mu \mathrm{m}$ であった。これは 著者らが顎関節部の解析に必要と考える分解能 $50 \mu \mathrm{m}$ には及ばず，これを補正する方法について検討を加えた ところ，6 ポイント以上のデータを平均することにより 分解能を $50 \mu \mathrm{m}$ 以下とすることが可能であったことか ら，本実験においてもこの方法を用いた。

\section{ICP における MVC 時の下顎頭変位}

菅沼 ${ }^{18)}$ の研究によると, ICP における MVC 時の下 顎頭の変位は前後的には前方 $0.3 \mathrm{~mm}$ から後方 0.7 $\mathrm{mm}$, 上下的には $0.0 \mathrm{~mm}$ から上方 $0.8 \mathrm{~mm}$ で, 平均後 方に $0.1 \pm 0.2 \mathrm{~mm}$ ，上方に $0.2 \pm 0.2 \mathrm{~mm}$ である。本
表 1 Results of F-test between occlusal support conditions (F-value)

各咬合条件間に㧍ける $\mathrm{F}$ 検定結果（F 值）

Anteroposterior direction

\begin{tabular}{|c|c|c|c|c|}
\hline & ICP & Tyре 77 & Type66 & Type47 \\
\hline ICP & & 1.252 & $5.877^{\%}$ & 4.791 \\
\hline Type77 & & & $7.361^{\%}$ & $6.000 \%$ \\
\hline Type66 & & & & 1.227 \\
\hline Type47 & & 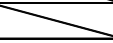 & & \\
\hline
\end{tabular}

Vertical direction

\begin{tabular}{|c|c|c|c|c|}
\hline & ICP & Type77 & Type66 & Type47 \\
\hline ICP & & 5.584 & 3.498 & 2.268 \\
\hline Type 77 & & 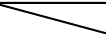 & 1.597 & 2.463 \\
\hline Type66 & 3 & & & 1.542 \\
\hline Type47 & & & & \\
\hline
\end{tabular}

Lateral direction

\begin{tabular}{|c|c|c|c|c|}
\hline & $\mathrm{ICP}$ & Type 77 & Type66 & Type47 \\
\hline ICP & & 1.536 & 2.243 & 2.692 \\
\hline Type77 & & ר & 1.460 & 1.753 \\
\hline Type66 & & r & & 1.200 \\
\hline Type47 & & The & & $10-10$ \\
\hline
\end{tabular}

$※: p<0.05$

研究では前後方向では前方 $0.33 \mathrm{~mm}$ から後方 0.03 $\mathrm{mm}$ ，上下方向では上方 $0.48 \mathrm{~mm}$ から下方 $0.16 \mathrm{~mm}$, 側方方向では外側 $0.15 \mathrm{~mm}$ から内側 $0.18 \mathrm{~mm}$ の範囲

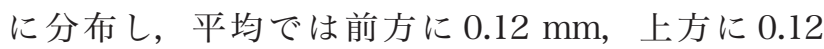
$\mathrm{mm}$ ，外側に $0.01 \mathrm{~mm}$ 変位した。閉口筋の作用方向か ら考えると咬みしめ時に下顎頭は上方へ引かれること が想定されるが，下方への変位を示すものがあった理由 としては下顎頭に回転が加わったことによる影響が考 えられる. 今回は平均的顆頭点にて測定を行っているた め，測定点が回転中心とは一致せず，回転中心が測定点 よりも前方にあった場合には下方への変位が生じる可 能性がある。

また，菅沼の研究では後方への変位が大きかったのに 対し本研究では前方への変位が多くみられた。これらの 違いは，菅沼の研究では下顎頭最上点をX線写真で観察 しており，この計測点と計測方法の違いか影響している と思われる。

他の研究を見ても, 下顎頭最上点をX線写真で観察し た早坂ら ${ }^{19)}$ の研究では後方へ変位するものが多く，一 方, 下顎運動測定装置を使用して測定した研究 ${ }^{16,17)}$ で は，本研究と同様に前方へ変位するという結果か報告さ れている。これらの下顎運動測定装置を使用した実験で は計測点を下顎頭外側や中央と想定しているため，下顎 頭最上点を観察した場合と比べると，下顎頭に回転が生 
じた場合変位方向が異なってくることが考えられるが, 機能時の下顎頭全体の移動の評価をするためには本研 究で用いたように下顎頭中央部が適していると考える。

なお，下顎運動測定装置を使用した測定方法では下顎 を剛体と仮定しているため，咬合力の負荷による骨の変 形や歯の変位などの影響を把握することができない，今 回の実験では頭部と下顎歯列に測定装置を装着してお り，下顗骨の変形や下顎歯列の変位が生じると，MVC 時の下顎頭の位置は実際よりも下方に表されている可能 性がある。竹内ら ${ }^{17)}$ の報告によると上㖽歯列変位の影 響量は垂直方向で平均 $63 \mu \mathrm{m}$ であり，下顎歯列変位に よる影響量をこれと同程度かこれ以下と推定すると本研 究における MVC 時の下顎頭位は実際よりも平均 $63 \mu \mathrm{m}$ 程下方に示されている可能性がある。本研究結果は，菅 沼 ${ }^{18)}$ の結果と比較すると上下的変位の平均が $0.08 \mathrm{~mm}$ 下方となり，これにはこのような下顎歯列変位や咬合力 の負荷による骨の変形などが影響していると考えられ る。このように咬みしめ時の下顎頭の計測方法による差 はあるものの本研究結果は他の研究結果 ${ }^{16-19)}$ の範囲と ほぼ一致しており，解析結果は妥当なものと考元る。

\section{MG 装着時における MVC 時の下顎頭変位}

$\mathrm{MVC}$ 時の下顎頭の変位方向には下顎周囲筋の作用方向 とその合力が大きく影響すると考えられる。前田ら ${ }^{21,22)}$, 森ら ${ }^{23)}$ の行った生体力学的シミュレーション実験では, 材質が柔らかくなることにより，咬みしめた際に下顎位 がより前上方に移動しやすくなり，その結果，下㖽頭が より下顎窩に近接することが示され，その程度は下顎頭 や下顎窩の形態ならびに位置関係に影響される可能性 が高いことを報告している，本研究の結果もこの生体力 学的シミュレーション実験同様前上方に下顎頭の変位 するものが多くみられ，特に Type77，Type66 装着時 に下顎頭の上方への変位が大きくなる傾向がみられた。 これについては被験者による差も大きいが，咬合挙上さ れていることにより MVC 時の上方への下顎頭変位量が 大きくなることに加え, Type77, Type66 という前歯 部咬合接触のある 2 条件で生じているため，前歯部の 咬合接触が何らかの影響を及ぼす可能性が考えられる。

Type77 において被験者 B が他の被験者と比べ上方へ の変位が大きくなったが，被験者 $\mathrm{B}$ は他の条件におい ても上方に変位し易く，発揮されている咬合力や筋の走 行, 顎関節の形態などが影響していることが推察される. また，MG で咬合挙上しているにも関わらず，被験者 H の Type66 で下方に 0.098 mm，Type47 で下方に $0.064 \mathrm{~mm}$ という少ない量であるが，下方への変位を示 した原因としては下顎頭に回転が加わったことによる
影響が推測される. Type66, Type47 という前後の咬 合支持を削除した条件で生じていることから，このこと により回転がより大きくなったことも考えられる。

硬質のスプリントを使用した研究 ${ }^{24)}$ では，下顎頭は MVC 時に前上方に変位し，後方の咬合支持を無くすこ とにより下顎頭の上方への変位が大きくなったという 報告がある．本研究では Type77 よりも後方の支持を喪 失させた Type66 では，前後的な下顎頭変位が各被験者 によって大きくばらつき上方，前上方へ変位するものが 多いものの，後方へ変位するものが増加した。これには 後方の咬合支持を喪失させることにより，下顎後方部の 上方への変位を支えることができず，硬質のスプリント ではそのまま下顎頭の上方への変位が大きくなるのに 対し，柔らかな材料を使用した $M G$ では下顎後方部が 上方へ変位するのに伴い $\mathrm{MG}$ 材が変形し下顎全体が後 方に変位することが考えられるが，これ以外にも $\mathrm{MG}$ では，初期の咬合状態，咬合挙上量なぞの違いや，軟質 の材料のため硬質の材料と比べ厳密な咬合調整ができ ないことなどが影響すると考えられる。

MG は固有の咬合状態に一時的に介入して顎口腔系の みならず全身的にも影響を与える可能性のある装置で ある、MG を装着することにより咬合高径が挙上され， 下顎頭と下顎窩との位置関係にも変化が生じることに なる、特に咬みしめ時にはスプリント装着時とは異なり, 材料に被圧縮性があるために顎位が変化し，下顎頭と下 顎窩の位置関係に変化が生じることになる。この状態で 安定した下顎位の維持には顎頸筋筋活動の増減による 調整が行われていると考えられる。

小池ら ${ }^{9)}$ は擬似的な短縮歯列の環境を作るために各 被験者の上顎歯列に適合する全歯列スプリント（常温重 合レジン製）を切歯部での挙上量を $2 \mathrm{~mm}$ となるよう 製作し，これを順次後方より切断することで咬合支持の 喪失時の咬みしめによる下顎頭変位を測定している。そ の結果によると第二大臼歯までの全ての咬合支持が 残つている条件において咬みしめ時の下顎頭変位量は 矢状面における直線距離で $0.6 \pm 0.2 \mathrm{~mm}$ であり，スプ リントを順次後方から喪失させるに伴いこの変位量は 大きくなる傾向にあり，また，喪失範囲の拡大とともに 被験者間のばらつきが増大することを明らかにしてい る。本研究では咬合挙上量が第一大鼠部で $2 \mathrm{~mm}$ ，材 質は EVAの MG であるが，小池らの第二大臼歯までの 全ての咬合支持が残っている条件に相当する Type77 に おいて MVC 時の下顎頭変位は上下方向に $0.53 \pm 0.43$ $\mathrm{mm}$ ，前後方向に $0.09 \pm 0.1 \mathrm{~mm}$ であり，咬みしめ開始 前の下顎頭位から MVC 時の下顎頭位までの矢状面にお ける直線距離は $0.54 \pm 0.43 \mathrm{~mm}$ と算出される。これに 
ついて小池ら ${ }^{9)}$ の結果と比較すると下顎頭変位量の平 均值は類似しているが，弾性材料を使用した本研究では 被験者により変位量はより大きくばらつく傾向にある ことがわかる。

前歯部の咬合接触の有無による影響については Type47 では前後方向のばらつきがType77 に比べ大き くなった。これは前歯部の支持を失うことにより前後的 に不安定となり生じたばらつきであると思われるが，変 位方向は被験者により異なり, Type77 装着時よりも前 方への変位量が増すものと Type77 装着時よりも後方へ の変位量が増すものに分かれた。これは前歯部歯根膜か らのフィードバックが筋活動に影響した結果とも考えら れ，非装着時における患者固有の咬合接触もこの違いに 影響する可能性がある ${ }^{25-27)}$ 。 また，マウスガードの前歯 部咬合接触には危険を察知した際に上下顎の前歯部歯列 とマウスガードが一体化し, 歯や歯列を保護するという 役割もあるため ${ }^{28)}$, 本研究における Type47 は咬みしめ 時においても咬合接触しない状態としたが, 実際の臨床 では，歯や歯列の保護を考えると前歯部は軽く咬合した 状態では咬合接触させなかったとしても，咬みしめ時に は接触するように調整する必要があると考える。これに より今回生じた Type47 の被験者間の前後的なばらつき が少なくなる可能性もあり, 今後は前歯部の咬合接触の 程度による影響の検討も必要と考える.

また各条件において下頂頭の変位方向は一律ではな く個人差があった。これには各閉口筋の作用方向や筋活 動量の違い, 顎関節部の解剖学的形態, 咬合力重心の違 いや咬合平面の傾きの違いなどが影響し, さらに前述の ように材料の被圧縮性や初期の咬合状態, 咬合挙上量, 軟質の材料のため硬質の材料と比べ厳密な咬合調整が できないことなども影響すると考えられる。本研究にお いては 3 種類の各 MG は, 1 つの MG を製作した後に 切断や削除するなどして咬合支持領域を変化させるの ではなく，3 種類それぞれに製作し調整を行っている. この方法で危惧される点は, それぞれの咬合挙上量や咬 合接触状態などに違いが生じる可能性があり, これらの 違いが下顎頭変位に影響し, 結果にも影響する可能性が あることである。一方，1つの MG を製作した後に切 断や削除する方法では, 測定順序が決まってしまいラン ダムに計測を行うことができず疲労の影響を排除でき ない. また，切断や削除する方法では今回の 3 種類の 場合は Type47 と Type66 のどちらかは行うことができ なくなってしまうことから, 今回は 3 種類それぞれに 製作する方法で行った。このため, MGの製作にあたつ ては方法の頁で述べた通り各 $\mathrm{MG}$ 間に極力違いが生じ ないような製作方法をとつた。
中島 ${ }^{29)}$ は，咬合支持領域の違いが咀嚼筋筋活動に及 ぼす影響についてスプリントを用いた研究結果を報告 しており，咬筋，側頭筋の筋活動量は第二大臼歯までの 全歯列接触型で最大を示し，大臼歯の支持を言失させた ものではそれよりも小さくなるとしている，また，前田 $ら^{25)}$ は, マウスガード装着時の下顎位の変位と咀嚼筋 筋活動について報告しており，マウスガード装着時の咬 みしめにおいて後下方への切歯点の移動がみられた場 合側頭筋の筋活動が有意に大きくなり, 後上方への切歯 点の移動がみられた場合には咬筋の活動量が有意に大 きくなる場合が多かったとしている，本研究では MVC の強さについて筋活動量などを設定せず，被験者の自然 な最大咬みしめを採用しており, MVCの強さの違いが 下顎頭変位に影響を及ぼす可能性があるが，中島 ${ }^{29)}$ の 報告のように咬合支持領域が変化することにより各筋 の筋活動のバランスも変化することが考えられ，今回は 筋活動を意図的に設定して決めるのではなく，被験者の 自然な最大咬みしめを採用した。

また，本研究においては筋活動量や切歯点などの下顎 位の移動については測定しておらず，今後これらとの関 係についても検討する必要があり, さらに, 各被験者の 咬合力や咬合接触状態ごとにグループ分けし，被験者 個々の条件が, 下顎頭変位の傾向に関連があるかについ ても検討する必要があると考える。また，本研究では $\mathrm{MG}$ 装着時の咬みしめによる下顎頭変位はより少なく安 定していることが望ましいのではないか? その安定性 には咬合接触の違いが影響するのではないか？という 仮説から咬みしめ時の下顎頭変位量とそのばらつきに ついて検討を行ったが，顎関節に与える影響について検 討するためにはさらに ICP での下顎頭位に対する位置 についても今後調べる必要がある.

本研究は咬みしめ時の下顎頭の変位量, 変位方向, と いう顎関節への影響の一端を示したに過ぎず，この結果 から臨床的にどの咬合接触を採用すべきか, 顎関節にど の程度の影響が生じるかを判断することは困難である が，これまでに MG 装着時の下顎頭位を定量的に評価 した報告はなく, 本研究において変位量, 変位方向, 被 験者間のばらつきを明らかにしたことは重要なポイン トであり, 今後の研究方針を決める上でも必要なデー夕 となると考える.

\section{V. 結 論}

$\mathrm{MG}$ の咬合支持領域の違いと MVC 時の下顎頭変位様 相との関連性を明らかにするために健常有歯顎者 10 名 に 3 種類の $\mathrm{MG}$ を装着し, 下顎頭変位を超音波方式に 
よる下顎運動機能解析装置である Win Jaw System ${ }^{\circledR}$ を 用いて測定し，以下の結論を得た。

1. MVC 時の下顎頭位のばらつきは前後方向では ICP に比べ Type66 のばらつきが有意に大きくなり, Type77 に比べ Type66 と Type47 のばらつきが有 意に大きくなった。このことより，前後の咬合支持 を削除することにより， MG 装着者個々によっては 前後的な安定性が減少することが示唆された。

2. 各咬合支持条件における下顎頭の変位量，変位方向 は個人差が大きく，どのような咬合接触が適切であ るかについては明確な結論は得られなかった。

\section{文献}

1）歯科医学大事典編集委員会編（代表 関根 弘)。歯科 医学大事典 第 2 巻, 東京：医歯薬出版；1987, 671 .

2) Labella CR, Smith BW, Sigurdsson A. Effect of mouthguards on dental injuries and concussions in college basketball. Med Sci Sports Exerc 2002; 34: 41-44.

3）竹内正敏，前田芳信，山田純子ほか. 女子水球競技へ のカスタムメイドマウスガード普及の取り組み、スポー ツ歯学 2003; 6: 51-55.

4）住吉周平，南部敏之，本田武司ほか。 マウスガードの スポーツ外傷予防効果 オトガイ部打撲を想定した有 限要素分析。日口外誌 1996; 42: 1192-1199.

5）日本スポーツ歯科医学会編。スポーツ歯科臨床マニュ アル，東京：医学情報社；2007, 57-60.

6）渥美陽二郎，佐藤大樹，宇野清博ほか。著明な咬耗を 有する部分欠損患者に対しカスタムメイドマウスガー ドで対応した症例。スポーツ歯学 2008; 11: 112-118.

7) Kozawa T, Igarashi Y, Yamashita S. Posterior occlusal support and bite force influence on the mandibular position. Eur J Prosthodont Rest Dent 2003; 11: 33-40.

8) Kirihara T, Yamashita S, Igarashi Y. Mandibular dispracement related to simulated loss of posterior occlusal support. Eur J Prosthodont Rest Dent 2005; 13: 170-176.

9）小池秀行，山下秀一郎，橋井公三郎ほか。咬ぬしめ時 の下顎頭変位と矢状顆路傾斜角との関連性。補綴誌 2007; 51: 546-555.

10）武田友孝，石上惠一，Dorney B ほか. ラミネートマウ スガードの製作法 (エリートタイプ)。スポーツ歯学 2000; 3: 46-56.

11) Korda $\beta$ B, Rückert B, Stüttgen U. Zur länge und lage der interkondylarachse. Dtsch Zahnärztl Z 1997; 52: 1-4.

12) Okeson JP. The effects of hard and soft occlusal splints on nocturnal bruxism. J Am Dent Assoc 1987; 114: 788-791.

13）前田芳信, 安井利一，米畑有理著編。マウスガード製 作マニュアル スポーツ歯学への誘い, 東京 : クイン テッセンス出版；2001, 69-78.
14）日本スポーツ歯科医学会編。スポーツ歯科臨床マニュ アル，東京：医学情報社；2007, 69-83.

15) Yamanaka T, Ueno T, Oki M et al. Study on the effects of shortening the distal end of a mouthguard using modal analysis. J Med Dent Sci 2002; 49: 129-133.

16）橋本和佳, 山本一道, 横山 隆ほか。 スタビリゼイショ ン・スプリント装着時のかみしめ時下顎頭位について。 補綴誌 2000; 44: 690-695.

17）竹内久裕，藤村哲也，坂東永一，咬合力による顎口腔系 の変形が顎運動解析に及ぼす影響。補綴誌 1990; 34: 1150-1161.

18）菅沼岳史. 咬頭嵌合位における咬みしめ時の顆頭変位. 補綴誌 1993; 37: 98-106.

19）早坂正博，高橋健二，酒井靖彦ほか. Sectograph によ る顆頭位の研究 第 2 報 咬合力発現時における顆頭 の移動について。補経誌 1983; 27: 573-584.

20）渥美陽二郎，菅原佳広，後藤基誉ほか. Win Jaw シス テム ${ }^{\circledR} に お け る$ 顎関節位置評価 (EPA) の精度。日顎誌 2006; 18: 43.

21）前田芳信，森 孝雄，前田憲昭ほか、顎関節の形態的 変化に関する生体力学的シミュレーション 第 1 報 顎関節部の応力分布に影響を与える因子について。日 㖽誌 1991; 3: 1-9.

22）前田芳信，栄村 勲。マウウスガードの機能と装着によ る影響。歯科ジャーナル 1992; 36: 525-535.

23）森 孝雄, 前田芳信, 堤 定美ほか. 顎関節部の形態 的変化敒関する生体力学的シミュレーション 第 2 報 下顎頭の前頭断面の形態差. 日顎誌 1992; 4: 10-18.

24) Seedorf H, Seetzen F, Scholz A et al. Impact of posterior occlusal support on the condylar position. J Oral Rehabil 2004; 31: 759-763.

25）前田芳信，栄村 勲，池原晃生ほか。ママウスガードの 装着が嶺口胿系に与える影響 第 1 報 筋活動ならび に下顎位について。補綴誌 1993; 37: 18-25.

26）栄村 勲，前田芳信，尾上祐悦ほか. T-Scan system の臨 床応用に関する研究 第 2 報 マウスガードの形態が咬 合力の分布に与える影響。阪大歯学誌 1990; 35: 441-446.

27）前田芳信，栄村 勲，尾上祐悦ほか. マウスガードの 装着が咬合力の分布に与える影響。阪大歯学誌 1990; 35: 557-563.

28）中島一憲，小川 透，川村慎太郎ほか. マウスガード の前歯部咬合接触が安全性に及ぼす影響 咬合力の影 響。歯科学報 2003; 103: 49.

29）中島一憲。顎口腔系の状態と全身状態との関連に関す る研究 咬合支持領域の大小が頸部後屈力と頸部筋お よび咀嚼筋筋活動とに及ぼす影響。補綴誌 1997; 41: 593-603.

\footnotetext{
著者連絡先：白野 美和 干 951-8580 新潟市中央区浜浦町 1-8 TEL : 025-267-1500 FAX : 025-267-1661 E-mail : marumiwa@ngt.ndu.ac.jp
} 


\title{
Influence of Occlusal Support of Mouthguard on Condylar Displacement during Clenching
}

\author{
Miwa Shirono, DDS, $\mathrm{PhD}^{\mathrm{a}}$, Kazuhiro Nagata, DDS, $\mathrm{PhD}^{\mathrm{a}}$ and Osami Morita, DDS, $\mathrm{PhD}^{\mathrm{b}}$ \\ ${ }^{a}$ Comprehensive Dental Care Unit and TMD clinic, The Nippon Dental University Niigata Hospital \\ ${ }^{\mathrm{b}}$ The Nippon Dental University
}

Ann Jpn Prosthodont Soc $1: 386-395,2009$

\begin{abstract}
Purpose: The effect of a mouthguard (MG) on the temporomandibular joint remains unclear. In this study, we aimed to clarify how differences in the occlusal MG support affect condylar displacement during clenching, by determining and examining the condylar displacement during maximal voluntary clenching (MVC) for three different kinds of occlusal support.

Methods: The study consisted of ten healthy adults (mean age:27 years) with healthy natural dentition. Three different kinds of occlusal MG support were prepared (Type 77 provided occlusal contact for all teeth, from the anterior teeth to the second molar; Type 66 provided occlusal contact up to the first molar; and Type 47 provided only posterior occlusal contact). Condylar displacement during MVC was determined by the Win Jaw system ${ }^{\circledR}$ (ultrasonic motion analyzer) for the intercuspal position (ICP) and while wearing the three kinds of MG support. Results: Compared to ICP, the extent of condylar displacement during MVC was significantly greater for superior displacement of Type 77 and Type 66.Furthermore, compared to ICP data, anteroposterior displacement was significantly greater for Type 66,and was significantly greater for Type 66 and Type 47, compared to Type 77 .

Conclusion: It was also found that loss of anterior or posterior occlusal support decreased anteroposterior stability. There was significant individual variation in the distance and direction of condylar displacement under each occlusal support condition. This study could not identify which occlusal support condition was better.
\end{abstract}

\section{Key words}

mouthguard, temporomandibular joint, condylar displacement, occlusal support, ultrasonic motion analyser 